\title{
Short communication: Effect of barn climate and management- related factors on bovine colostrum quality
}

\author{
E. Zentrich, M. Iwersen, M.-C. Wiedrich, M. Drillich, and D. Klein-Jöbstl* \\ Clinical Unit for Herd Health Management, University Clinic for Ruminants, Department for Farm Animals and Veterinary Public Health, \\ University of Veterinary Medicine, Vienna, 1210 Vienna, Austria
}

\begin{abstract}
Several factors have been reported to influence colostrum quality (immunoglobulin concentration). To date, knowledge of the influence of climatic factors in association with other potential influencing factors on colostrum quality is scarce. Associated influential factors are parity, body condition score, length of dry period, ration fed ante partum (AP), $\beta$-hydroxybutyrate postpartum (PP), milk yield, milk fat and protein, as well as somatic cell counts from previous and current lactation. The objective of the present study was to examine the effect of barn climate and the aforementioned factors on colostrum quality. Data were collected from 1,381 multiparous Holstein Friesian cows kept on one dairy farm over a period of one year (August 2014 to August 2015). Colostrum was harvested on farm within $1 \mathrm{~h}$ PP. The quantity and quality of first colostrum (estimated by Brix refractometry) were recorded for each cow. Additional data recorded were parity, body condition score at drying off, length of dry period, ration fed AP, milk yield data from previous and current lactation, milk somatic cell counts, and $\beta$-hydroxybutyrate PP. During the study period, temperature and humidity were recorded in the barn every hour, and temperature-humidity index (THI) was calculated. Linear regression was performed with colostrum quality as the dependent variable. In the final model, colostrum quantity (L), length of dry period, parity, and climatic factors (specifically, median humidity in the $3 \mathrm{rd}$ week $\mathrm{AP}$ and hours with THI $\geq 72$ in the last 14 and 21 d AP, respectively) were significant. Colostrum quality improved with parity and length of dry period and decreased with colostrum quantity, humidity, and hours with a THI $\geq 72$. A classification and regression tree analysis revealed that colostrum quantity was the most important factor in this model [normalized importance (NI) 100\%]. Parity (NI 42.7\%), length of dry period (NI
\end{abstract}

Received September 4, 2018.

Accepted April 22, 2019.

*Corresponding author: Daniela.Klein@vetmeduni.ac.at
$37.1 \%$ ), and climatic factors (NI 0.4 to $1.9 \%$ ) followed with decreasing importance. These results indicate that the most important factors for colostrum quality (i.e., colostrum quantity and parity) may not be influenced by management. The 2 factors that can be influenced by management [i.e., length of dry period and THI (e.g., by cooling)], were quantitatively of minor importance compared with the other 2 factors. Further studies are necessary to determine whether changing these factors can improve colostrum quality significantly.

Key words: colostrum quality, temperature-humidityindex, parity, length of dry period, colostrum quantity

\section{Short Communication}

Colostrum quality is of importance for adequate passive transfer of immunoglobulins to the newborn calf. Immunoglobulin $\mathrm{G}$ is generally used as a measure of colostrum quality due to its increasing concentration during colostrum formation ante partum (AP) and its preferential absorption into calf serum (Brandon et al., 1971; Johnsen et al., 2019). Several weeks before calving, especially during the last 2 to $3 \mathrm{wk} \mathrm{AP}$, the transport of immunoglobulin from the maternal serum into the milk gland begins, induced by hormones (Baumrucker and Bruckmaier, 2014). In addition to immunoglobulin, colostrum contains cytokines and leukocytes that are of immunological importance (Gonzalez and Dus Santos, 2017). Quantification of cells in colostrum is difficult, which could explain why colostrum quality is defined by immunoglobulin concentration (Shivley et al., 2018). Colostrum quality (as determined by immunoglobulin concentration) may be influenced by several factors [e.g., parity, colostrum quantity, time of first colostrum harvesting, and length of dry period (Morin et al., 2010; Conneely et al., 2013; Silva-Del-Río et al., 2017)].

Previous studies examined the effect of heat stress on colostrum quality by comparing cooled and not cooled cows at the same ambient temperature-humidity index (THI) and found contradictory results (Adin et al., 2009; Tao et al., 2012; Monteiro et al., 2014; Karimi et al., 2015; Laporta et al., 2017). To our knowledge, no 
previous studies have analyzed the effect of different climatic factors on colostrum quality independent of cooling during heat stress.

Consequently, the objective of our study was to analyze different factors that may have an effect on colostrum quality, with a focus on the influence of barn climate, and to determine factors associated with colostrum quality that can be used for management decisions on farm.

The hypothesis of the study was that colostrum quality (defined by immunoglobulin concentration determined by Brix refractometry) is influenced by barn climate and other factors that can be addressed using on-farm management strategies.

The study was conducted on a dairy farm with approximately 2,500 Holstein Friesian cows in Slovakia from August 2014 to August 2015. Only cows in second or higher lactation were housed on farm and, therefore, no primiparous cows were included in the study. Lactating cows were housed in freestall barns. Approximately $60 \mathrm{~d}$ before expected calving, all cows were dried off abruptly at the end of the designated milking and received intramammary dry cow treatments with $150 \mathrm{mg}$ of cefquinome (Virbactan, Virbac, Carros, France) and internal teat sealants $(2.6 \mathrm{~g}$ of bismuth subnitrate in 4 $\mathrm{g}$ of suspension, Orbeseal, Zoetis, Florham Park, NJ). At drying off, BCS was determined on a 5-point scale with quarter-point increments (Edmonson et al., 1989) routinely by one trained farm worker. Body condition scores were categorized according to Heuwieser (1991) into under-conditioned $(<3.25)$, optimal (3.25-3.75), and over-conditioned (>3.75). Approximately $3 \mathrm{wk}$ before calving, cows were moved to the close-up area and housed in deep straw-bedded group pens. In this area cows were fed a close-up TMR. The ration was calculated for maintenance (700 $\mathrm{kg}$ of $\mathrm{BW})$ and the production of $10 \mathrm{~kg}$ of milk (with $4.00 \%$ fat and $3.40 \%$ protein). Mean daily DMI per cow was $13.7 \pm 0.1 \mathrm{~kg}$, mean $\mathrm{NE}_{\mathrm{L}}$ was $5.9 \pm 0.1$ per $\mathrm{kg}$ of $\mathrm{DM}$, and mean digestible CP was $145 \pm 1.7 \mathrm{~g} / \mathrm{kg}$ of DM. During the study period, the ration changed 3 times. Forage composition changed once with addition of sorghum to corn silage, grass silage, hay, and straw and quantities of the components changed twice. Around the time of calving, cows were constantly monitored. After calving cows were moved to the fresh cow area. During the study period, temperature $(\mathbf{T})$ and relative humidity (RH) were recorded in the close-up area every hour by a calibrated data logger (Tinytag-Gemini Dataloggers Ltd., Chichester, United Kingdom) placed at the level of the cows' heads. Climate data were downloaded from the logger and transferred into Excel (Microsoft Corp., Redmond, WA). Using these data, the THI was calculated for each hour using the formula of Kendall and Webster (2009): THI $=(1.8 \mathrm{~T}+32)$ $-[(0.55-0.0055 \mathrm{RH})(1.8 \mathrm{~T}-26)]$. For each cow, the following climate conditions in the close-up area were calculated: temperature, humidity, THI (median, minimum, maximum), and number of hours with THI $\geq 72$ in the intervals of 3,2 , and 1 wk before parturition. Regarding feeding and climatic factors, we focused on the last 3 wk before calving, as colostrogenesis mainly occurs during this period. Within $1 \mathrm{~h}$ after calving, first colostrum was machine milked into an individual bucket with a scale with increments of $100 \mathrm{~mL}$. Colostrum quantity (L) was recorded by the farm personnel. Colostrum quality was immediately estimated using a calibrated Brix refractometer (Digital Refractometer HM-DREF-1, Hebesberger Messtechnik, Neuhofen, Austria). This method is currently the most suitable on-farm tool, although sensitivity varied between 79.0 and $97.2 \%$, and specificity between 62.5 and $86.0 \%$ in previous studies (Bielmann et al., 2010; Quigley et al., 2013; Vandeputte et al., 2014; Bartens et al., 2016). The date and time of calving, sex, and ear tag number of the calf were also noted. Additional data used in the study were 305-d standard lactation performance in previous lactation, days in close-up area, parity, SCC at drying off, daily milk yield in the first 4 wk postpartum (PP), SCC, daily milk yield, milk protein content (\%), milk fat content (\%), and ECM yield $(\mathrm{kg})$ on the first milk test day. $\beta$-Hydroxybutyrate concentration ( $\mathrm{mmol} / \mathrm{l}$ ) was measured in blood, sampled once between the 2nd and 14th day PP (median 5th d PP) by puncture of tail vessels and on-farm testing using a handheld device (FreeStyle Precision Neo, Abbott GmbH \& Co. KG, Wiesbaden, Germany; Iwersen et al., 2013; Kanz et al., 2015). All farm data were recorded in DairyCOMP 305 (Valley Agricultural Software, Tulare, CA).

Data were statistically analyzed using SPSS Statistics for Windows (version 24.0, IBM Deutschland GmbH, Ehningen, Germany). Linear regression with colostrum quality as the dependent variable was used to examine the associations between colostrum quality and the different independent variables. Before inclusion in the multiple linear regression model, all independent variables were tested for correlation by Pearson's correlation or Spearman's rank correlation (depending on the type of variable). If a correlation exceeded 0.60 , one of the covariates was chosen for the model by taking biological plausibility into account. A backward stepwise elimination of nonsignificant variables was performed to obtain a model containing only significant variables. The level of significance was set a priori at $P<0.05$. Interactions were considered and evaluated for significance. The assumptions for linear regression, multivariate normality, no or little multicollinearity, no auto-correlation, and homoscedastic- 
Table 1. Multiple linear regression with colostrum quality as dependent variable ${ }^{1}$

\begin{tabular}{lcc}
\hline Independent variable & $\begin{array}{c}\text { Regression } \\
\text { coefficient }\end{array}$ & $P$-value \\
\hline Constant & 20.559 & $<0.01$ \\
Colostrum quantity & -0.363 & $<0.01$ \\
Length of dry period & 0.033 & $<0.01$ \\
Parity & 0.466 & $<0.01$ \\
Median RH in the 3rd week AP & 0.022 & 0.013 \\
Constant & 22.356 & $<0.01$ \\
Colostrum quantity & -0.365 & $<0.01$ \\
Length of dry period & 0.032 & $<0.01$ \\
Parity & 0.472 & $<0.01$ \\
Hours with THI $\geq 72$ last 14 d AP & -0.004 & 0.025 \\
Constant & 22.192 & $<0.01$ \\
Colostrum quantity & -0.366 & $<0.01$ \\
Length of dry period & 0.032 & $<0.01$ \\
Parity & 0.538 & $<0.01$ \\
Hours with THI $\geq 72$ last $21 \mathrm{~d}$ AP & -0.002 & 0.031 \\
\hline
\end{tabular}

${ }^{1}$ The 3 best-fitting models (using Akaike information criterion) with either median relative humidity $(\mathrm{RH})$ in the $3 \mathrm{rd}$ week ante partum (AP), or hours with temperature-humidity index (THI) $\geq 72$ during the last 14 or $21 \mathrm{~d}$ AP are presented.

ity were met. As climate data highly correlated, the model was run for each climate variable separately. The Akaike information criterion based on goodness of fit was chosen to compare the different models. Results for the models with the lowest Akaike information criterion are presented (Table 1). A classification and regression tree (CART) analysis was carried out, and the tree was pruned to avoid overestimation. The minimum case count was set at 100 for the superordinate node and 50 for the subordinate node. The importance of independent variables is a measure of how much the network's predicted value changes for different values of the independent variable. The normalized importance is the importance values divided by the largest importance values and expressed as percentages (Alabi et al., 2013).

Colostrum quality varied between 9.3 and $42.0 \%$ Brix (median 23.2, interquartile range 21.7-25.3\%).

The minimum temperature during the study period was $-8.2^{\circ} \mathrm{C}$ and the maximum was $39.2^{\circ} \mathrm{C}$. Humidity ranged from 21.5 to $100 \%$. The THI varied between 21.0 and 83.1 during the study period. Throughout the study, cows were exposed to a THI $\geq 72$ within the last 3 wk ante partum (AP) for between 0 and $325 \mathrm{~h}$.

In the final multiple linear regression model, the following variables were significant: colostrum quantity, length of dry period, parity, and either median $\mathrm{RH}$ in the 3rd week AP, maximum $\mathrm{RH}$ in the $3 \mathrm{rd}$ and 2 nd week AP, maximum RH during the last 21,14 , and $7 \mathrm{~d}$ $\mathrm{AP}$, or hours with THI $\geq 72$ during the last 21,14 , and 7 d AP (Table 1). Colostrum quality improved with parity and length of dry period, and decreased with colostrum quantity, $\mathrm{RH}$, and hours with a THI $\geq 72$. We could not detect any interaction or confounding in our model. It is possible that colostrum quality was influenced by other, nonevaluated factors.

The CART (Figure 1) analysis showed a cut-off for good colostrum quality at $8.75 \mathrm{~L}$ of colostrum. If colostrum quality was below this cut-off, parity had an influence on colostrum quality. If parity was higher than 2, then the mean colostrum quality was higher. Furthermore, if colostrum quantity was over $8.75 \mathrm{~L}$, a length of dry period $>56.5 \mathrm{~d}$ increased colostrum quality. Normalized importance (NI) was calculated in the CART analysis and revealed highest importance for colostrum quantity (NI 100\%), followed by parity, length of dry period, and hours with THI $\geq 72$ during the last $21 \mathrm{~d}$ AP with decreasing importance (in regard to colostrum quantity), with a NI of $42.7,37.1$, and $1.9 \%$, respectively. Other climatic factors (e.g., median $\mathrm{RH}$ in the 3rd week AP or hours with THI $\geq 72$ during the last $14 \mathrm{~d}$ AP) showed even a lower NI (0.5 and $0.4 \%)$.

Although climatic influences before calving had a significant effect on colostrum quality, the CART analysis illustrated the low importance of this variable compared with the other significant variables (colostrum quantity, parity, and length of dry period). A possible explanation could be that the study was carried out on a farm located in the moderate climatic zone. Under subtropical or tropical conditions, more extreme climatic conditions might have a more pronounced influence.

Several studies showed that colostrum quality was significantly better in cows in third or higher lactation than in cows in second lactation (Conneely et al., 2013; Angulo et al., 2015; Karl and Staufenbiel, 2017). Possible explanations are, that older cows have been exposed to more pathogens during their lifetime compared with younger cows and, in response, produce more IgG and that the transport of IgG into the mammary gland may be associated with maximal mammary gland development (Devery-Pocius and Larson, 1983; Conneely et al., 2013). Targeted studies are necessary to elucidate this.

Consistent with literature, our study found that colostrum quantity was significantly associated with colostrum quality (Chuck et al., 2017; Denholm et al., 2018). This finding can perhaps be explained by increased secretion and the osmotic effects of lactose (that can differ significantly in colostrum; Morrill et al., 2012; Dunn et al., 2017), leading to dilution (Pritchett et al., 1991; Conneely et al., 2013).

The length of dry period also had a significant effect on colostrum quality, although the CART analysis 


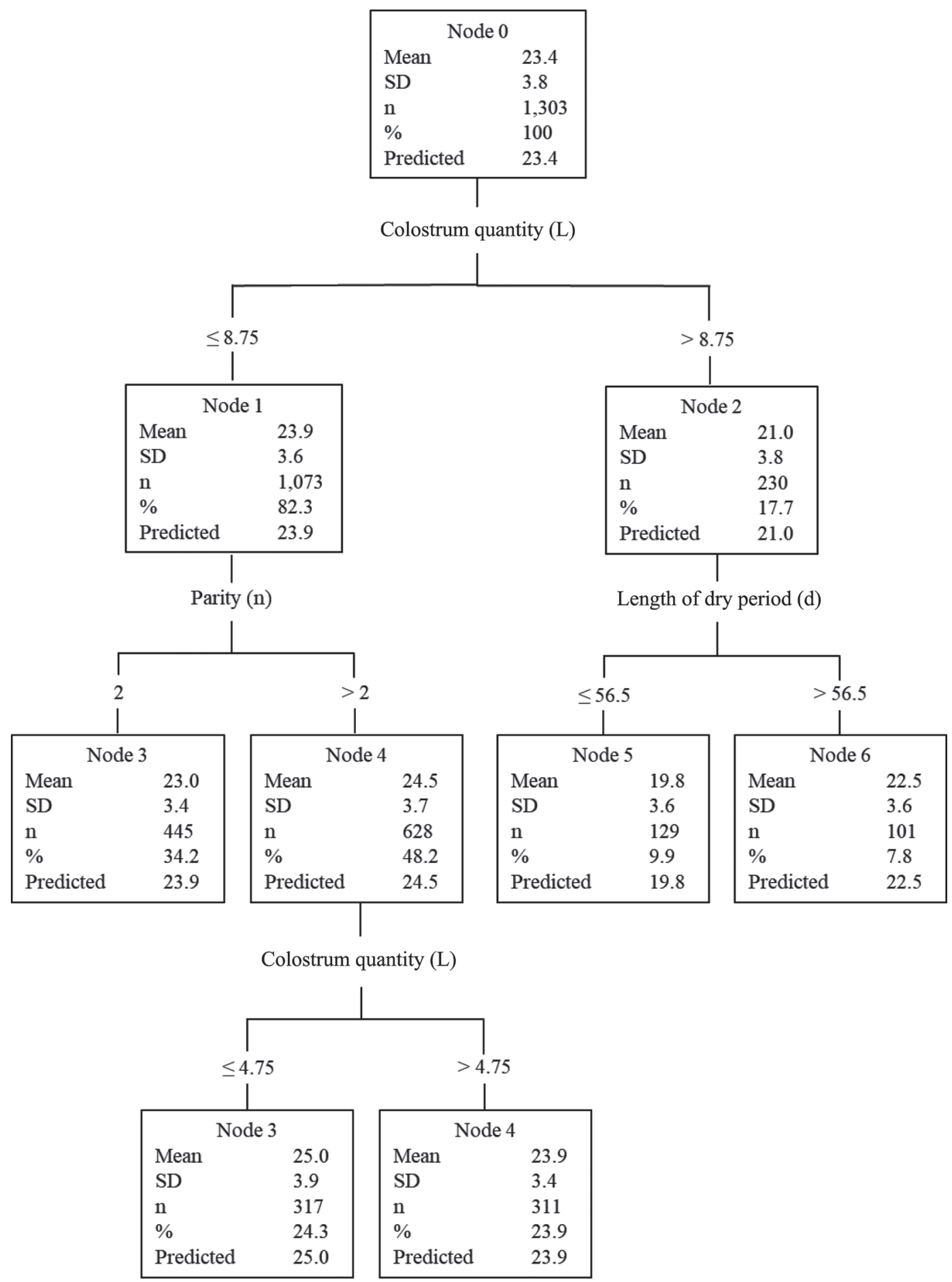

Figure 1. Classification and regression tree analysis with colostrum quality as the outcome variable.

showed that this only applies if colostrum quantity is above $8.75 \mathrm{~L}$. This may be one reason why the results of previous studies are contradictory (Watters et al., 2008; Mansfeld et al., 2012; Shoshani et al., 2014; Karl and Staufenbiel, 2017).
It is important to identify on-farm factors associated with colostrum quality that can be influenced by management. In the present study these were the length of the dry period and climatic factors such as humidity and THI. As the importance of these factors was low 
compared with the other significant factors, further studies will be needed to evaluate whether optimizing length of dry period and improving barn climate (e.g., by cooling) can increase colostrum quality to a meaningful extent on farm.

\section{ACKNOWLEDGMENTS}

We thank First Farms Agro (Plavecký Štvrtok, Slovakia) and Lars Meyer (First Farms Agro, Plavecký Stvrtok, Slovakia) for the opportunity to perform this study. Furthermore, we thank the Austrian Association for Buiatrics (ÖBG, Vienna, Austria) for financial support and Alexander Tichy (Bioinformatics and Biostatistics Platform, Department of Biomedical Sciences, University of Veterinary Medicine, Vienna, Austria) for supervision in statistics.

\section{REFERENCES}

Adin, G., A. Gelman, R. Solomon, I. Flamenbaum, M. Nikbachat, E. Yosef, A. Zenou, A. Shamay, Y. Feuermann, S. J. Mabjeesh, and J. Miron. 2009. Effects of cooling dry cows under heat load conditions on mammary gland enzymatic activity, intake of food and water, and performance during the dry period and after parturition. Livest. Sci. 124:189-195. https://doi.org/10.1016/j.livsci 2009.01.014.

Alabi, M. A., S. Issa, and R. B. Afolayan. 2013. An application of artificial intelligent neural network and discriminant analyses on credit scoring. J. Modern Math. Stat. 7:47-54.

Angulo, J., L. M. Gómez, L. Mahecha, E. Mejía, J. Henao, and C. Mesa. 2015. Calf's sex, parity and the hour of harvest after calving affect colostrum quality of dairy cows grazing under high tropical conditions. Trop. Anim. Health Prod. 47:699-705. https://doi .org/10.1007/s11250-015-0781-z.

Bartens, M.-C., M. Drillich, K. Rychli, M. A. Iwersen, T. Arnholdt, L. Meyer, and D. Klein-Jöbstl. 2016. Assessment of different methods to estimate bovine colostrum quality on farm. N. Z. Vet. J. 64:263-267. https://doi.org/10.1080/00480169.2016.1184109.

Baumrucker, C. R., and R. M. Bruckmaier. 2014. Colostrogenesis: IgG1 transcytosis mechanisms. J. Mammary Gland Biol. Neoplasia 19:103-117. https://doi.org/10.1007/s10911-013-9313-5.

Bielmann, V., J. Gillan, N. R. Perkins, A. L. Skidmore, S. Godden, and K. E. Leslie. 2010. An evaluation of Brix refractometry instruments for measurement of colostrum quality in dairy cattle. J. Dairy Sci. 93:3713-3721. https://doi.org/10.3168/jds.2009-2943.

Brandon, M. R., D. L. Watson, and A. K. Lascelles. 1971. The mechanism of transfer of immunoglobulin into mammary secretion of cows. Immunol. Cell Biol. 49:613-623. https://doi.org/10.1038/icb .1971 .67 .

Chuck, G. M., P. D. Mansell, M. A. Stevenson, and M. M. Izzo. 2017. Factors affecting colostrum quality in Australian pasture-based dairy herds. Aust. Vet. J. 95:421-426. https://doi.org/10.1111/ avj.12643.

Conneely, M., D. P. Berry, R. Sayers, J. P. Murphy, I. Lorenz, M. L. Doherty, and E. Kennedy. 2013. Factors associated with the concentration of immunoglobulin $\mathrm{G}$ in the colostrum of dairy cows. Animal 7:1824-1832. https://doi.org/10.1017/S1751731113001444.

Denholm, K. S., S. McDougall, G. Chambers, and W. Clough. 2018. Factors associated with colostrum quality in individual cows from dairy herds in the Waikato region of New Zealand. N. Z. Vet. J. 66:115-120. https://doi.org/10.1080/00480169.2017.1418684.

Devery-Pocius, J. E., and B. L. Larson. 1983. Age and previous lactations as factors in the amount of bovine colostral immunoglobu- lins. J. Dairy Sci. 66:221-226. https://doi.org/10.3168/jds.S0022 $-0302(83) 81780-9$

Dunn, A., A. Ashfield, B. Earley, M. Welsh, A. Gordon, and S. J. Morrison. 2017. Evaluation of factors associated with immunoglobulin $\mathrm{G}$, fat, protein, and lactose concentrations in bovine colostrum and colostrum management practices in grassland-based dairy systems in Northern Ireland. J. Dairy Sci. 100:2068-2079. https://doi.org/ 10.3168/jds.2016-11724.

Edmonson, A. J., I. J. Lean, L. D. Weaver, T. Farver, and G. Webster. 1989. A body condition scoring chart for Holstein dairy cows. J. Dairy Sci. 72:68-78. https://doi.org/10.3168/jds.S0022 $-0302(89) 79081-0$

Gonzalez, D. D., and M. J. Dus Santos. 2017. Bovine colostral cellsThe often forgotten component of colostrum. J. Am. Vet. Med. Assoc. 250:998-1005. https://doi.org/10.2460/javma.250.9.998.

Heuwieser, W. 1991. Die Beurteilung der Körperkondition bei Milchkühen. Milchpraxis 29:130-132.

Iwersen, M., D. Klein-Jobstl, M. Pichler, L. Roland, B. Fidlschuster, I. Schwendenwein, and M. Drillich. 2013. Comparison of 2 electronic cowside tests to detect subclinical ketosis in dairy cows and the influence of the temperature and type of blood sample on the test results. J. Dairy Sci. 96:7719-7730. https://doi.org/10.3168/ jds.2013-7121.

Johnsen, J. F., H. Viljugrein, K. E. Boe, S. M. Gulliksen, A. Beaver, A. M. Grondahl, T. Sivertsen, and C. M. Mejdell. 2019. A cross-sectional study of suckling calves' passive immunity and associations with management routines to ensure colostrum intake on organic dairy farms. Acta Vet. Scand. 61:7. https://doi.org/10 $.1186 / \mathrm{s} 13028-019-0442-8$.

Kanz, P., M. Drillich, D. Klein-Jobstl, B. Mair, S. Borchardt, L. Meyer, I. Schwendenwein, and M. Iwersen. 2015. Suitability of capillary blood obtained by a minimally invasive lancet technique to detect subclinical ketosis in dairy cows by using 3 different electronic hand-held devices. J. Dairy Sci. 98:6108-6118. https://doi .org/10.3168/jds.2014-8957.

Karimi, M. T., G. R. Ghorbani, S. Kargar, and J. K. Drackley. 2015. Late-gestation heat stress abatement on performance and behavior of Holstein dairy cows. J. Dairy Sci. 98:6865-6875. https://doi .org/10.3168/jds.2014-9281.

Karl, M., and R. Staufenbiel. 2017. Einflussfaktoren auf die Immunglobulinkonzentration im Erstkolostrum bei Holstein-FriesianMilchkühen und deren Beziehung zur postpartalen Kalziumkonzentration im Blut und Kolostrum. Tierarztl. Prax. Ausg. G Grosstiere Nutztiere 45:331-341. https://doi.org/10.15653/TPG $-170382$.

Kendall, P. E., and J. R. Webster. 2009. Season and physiological status affects the circadian body temperature rhythm of dairy cows. Livest. Sci. 125:155-160. https://doi.org/10.1016/j.livsci.2009.04 .004 .

Laporta, J., T. F. Fabris, A. L. Skibiel, J. L. Powell, M. J. Hayen, K. Horvath, E. K. Miller-Cushon, and G. E. Dahl. 2017. In utero exposure to heat stress during late gestation has prolonged effects on the activity patterns and growth of dairy calves. J. Dairy Sci. 100:2976-2984. https://doi.org/10.3168/jds.2016-11993.

Mansfeld, R., C. Sauter-Louis, and R. Martin. 2012. Auswirkungen der Länge der Trockenstehzeit bei Milchkühen auf Leistung, Gesundheit, Fruchtbarkeit und Kolostrumqualität. Tierarztl. Prax. Ausg. G Grosstiere Nutztiere 40:239-250.

Monteiro, A. P. A., S. Tao, I. M. Thompson, and G. E. Dahl. 2014. Effect of heat stress during late gestation on immune function and growth performance of calves: Isolation of altered colostral and calf factors. J. Dairy Sci. 97:6426-6439. https://doi.org/10.3168/ jds.2013-7891.

Morin, D. E., S. V. Nelson, E. D. Reid, D. W. Nagy, G. E. Dahl, and P. D. Constable. 2010. Effect of colostral volume, interval between calving and first milking, and photoperiod on colostral IgG concentrations in dairy cows. J. Am. Vet. Med. Assoc. 237:420-428. https://doi.org/10.2460/javma.237.4.420.

Morrill, K. M., E. Conrad, A. Lago, J. Campbell, J. Quigley, and H. Tyler. 2012. Nationwide evaluation of quality and composition 
of colostrum on dairy farms in the United States. J. Dairy Sci. 95:3997-4005. https://doi.org/10.3168/jds.2011-5174.

Pritchett, L. C., C. C. Gay, T. E. Besser, and D. D. Hancock. 1991. Management and production factors influencing immunoglobulin G1 concentration in colostrum from Holstein cows. J. Dairy Sci. 74:2336-2341. https://doi.org/10.3168/jds.S0022-0302(91)78406 $-3$.

Quigley, J. D., A. Lago, C. Chapman, P. Erickson, and J. Polo. 2013. Evaluation of the Brix refractometer to estimate immunoglobulin G concentration in bovine colostrum. J. Dairy Sci. 96:1148-1155. https://doi.org/10.3168/jds.2012-5823.

Shivley, C. B., J. E. Lombard, N. J. Urie, C. A. Kopral, M. Santin, T. J. Earleywine, J. D. Olson, and F. B. Garry. 2018. Preweaned heifer management on US dairy operations: Part VI. Factors associated with average daily gain in preweaned dairy heifer calves. J. Dairy Sci. 101:9245-9258. https://doi.org/10.3168/jds.2017-14022.

Shoshani, E., S. Rozen, and J. J. Doekes. 2014. Effect of a short dry period on milk yield and content, colostrum quality, fertility, and metabolic status of Holstein cows. J. Dairy Sci. 97:2909-2922. https://doi.org/10.3168/jds.2013-7733.
Silva-Del-Río, N., D. Rolle, A. García-Muñoz, S. Rodríguez-Jiménez, A. Valldecabres, A. Lago, and P. Pandey. 2017. Colostrum immunoglobulin G concentration of multiparous Jersey cows at first and second milking is associated with parity, colostrum yield, and time of first milking, and can be estimated with Brix refractometry. J. Dairy Sci. 100:5774-5781. https://doi.org/10.3168/jds.2016-12394.

Tao, S., A. P. A. Monteiro, I. M. Thompson, M. J. Hayen, and G. E. Dahl. 2012. Effect of late-gestation maternal heat stress on growth and immune function of dairy calves. J. Dairy Sci. 95:7128-7136. https://doi.org/10.3168/jds.2012-5697.

Vandeputte, S., J. Detilleux, and F. Rollin. 2014. Investigation of colostrum quality in beef cattle by radial immunodiffusion and Brix refractometry. Vet. Rec. 175:353. https://doi.org/10.1136/vr .101590 .

Watters, R. D., J. N. Guenther, A. E. Brickner, R. R. Rastani, P. M. Crump, P. W. Clark, and R. R. Grummer. 2008. Effects of dry period length on milk production and health of dairy cattle. J. Dairy Sci. 91:2595-2603. https://doi.org/10.3168/jds.2007-0615. 